\title{
Colin Tyler
}

Department of Politics, University of Hull, United Kingdom

ORCID: 0000-0003-0338-9181

\section{Brexit: Hatred, lies and UK democracy*}

$27 / 2019$

Political Dialogues

DOI: http://dx.doi.org/10.12775/DP.2019.011

\begin{abstract}
:
This article analyses the Brexit debate within the UK. It examines the historical roots of the debate from 1973 when the UK joined the European Economic Community, but focuses primarily on the debates that occurred between 2013 when David Cameron pledged to hold a referendum up to the 2019 UK General Election. Section one briefly introduces the topic. Section two examines the rise of social hatred during the referendum campaign. It focuses on the history of British euroscepticism, the immediate context of the Brexit campaign, concerns over UK sovereignty and immigration, and the increasing use of threats and political violence. Section three examines the decline of trust in politics due to the increasing failure to challenge lies in the Brexit debate. It explores the idea of "Project Fear", the anti-expert narrative, and the anti-elitism narrative. Section four asks what this period tells us about UK democracy. It focuses on weak and disorderly government, the democratic status of the referendum, the erosion of trust in parliamentary institutions and mechanisms, and some reasons for (limited) optimism. The article concludes by considering possible ways forward for the UK government and polity following the decisive Conservative victory in the 2019 UK General Election.
\end{abstract}

Keywords; Brexit; democracy; European Union; fake news; political violence; populism; UK politics.

\section{Introduction}

A referendum was held in the United Kingdom (UK) on $23^{\text {rd }}$ June 2016, with the question of "Should the United Kingdom remain a member of the European Union or leave the European Union?"1 33,577,342 people voted; that is, $72.21 \%$ of the electorate $\left(46,500,001\right.$ people). ${ }^{2} 51.89 \%$ voted to leave and $48.11 \%$ voted to remain. In abso-

* I am grateful to Richard Barnes, Jim Connelly, Christopher Fear, Janusz Grygieńć, Pip Tyler and audience members at both Nicolaus Copernicus University, Poland and the Indian Institute of Technology Tirpuati, India, for their comments on and other help with an earlier version of this article. I bear sole responsibility for the use made of that help.

${ }^{1}$ UK Government, "EU referendum", GOV. UK, n.d., https://www.gov.uk/government/topicalevents/eu-referendum/about

2 BBC News, "EU Referendum: results", BBC News, n.d., https://www.bbc.co.uk/news/politics/ eu_referendum/results accessed 4 November 2019. 
lute numbers, $17,410,742$ voted to leave the EU while 16,141,241 voted to remain part of it.

This was neither the end nor the beginning of the process. And indeed some interesting difficulties have arisen since the Brexit referendum was called. Here, I will reflect on the events that led to the vote and those that have followed from it, as well as its significance for the UK. In particular, I will reflect on the hatred and lies that has surrounded the Brexit debate in the UK (a debate that has continued even after the 2019 UK General Election), and what implications the whole process has for a country that has long prided itself on its democratic institutions and traditions.

\section{Hatred}

\section{a. A brief historical introduction to UK euro- scepticism}

Profound resistance to European integration is historical in the UK as elsewhere. As with almost all of the UK's Brexit debate, it has been expressed by leading politicians in both the Conservatives and Labour parties. For example, throughout his long political career the prominent Conservative and later Unionist MP Enoch Powell voiced his implacable opposition to what he saw as the ultimately political mission of the EEC in all its subsequent forms. At the other end of the political spectrum, the Labour Party grandee, Tony Benn also maintained an implacable opposition to the EEC. For example on January 1963 he wrote:

"[T]he Treaty of Rome which entrenches laissez-faire as its philosophy and chooses $\mathrm{Bu}$ reaucracy as its administrative method will stultify effective national economic planning without creating the necessary supranational planning mechanisms for growth and social justice under democratic control. ... [T] political inspiration of the EEC amounts to a belief in the institutionalisation of NATO, which will harden the division of Europe and encourage the emergence of a new nuclear superpower, thus worsening East-West relations and making disarmament more difficult." 3

The Conservative Party has always had a particularly difficult relationship with European institutions. That makes it somewhat surprising that the UK gained membership of the European Economic Community (EEC) under a Conservative Prime Minister, the Europhile Edward Heath. As you know, the EEC was founded in 1957. For the next twelve years the UK drifted towards membership. French President Charles De Gaulle vetoed British applications for membership twice, in 1963 and 1967. De Gaulle died on 9 November 1970 and on 1 January 1973 the UK joined the EEC. The Labour Party came to power in February 1974 with Harold Wilson as Prime Minister. On 5 June 1975, the UK government held a referendum on Britain's continuing membership, with the Labour Party campaigning to remain. The electorate agreed with the government, when $67.23 \%$ of voters opted to stay in the European Community and $32.77 \%$ voted to leave.

The UK's subsequent relationship with the European institutions has been multifacetted, complex and continually shifting. Many UK politicians and citizens are pro-

3 Tony Benn, Encounter (January 1963), quoted in Ruth Winstone (ed.), Best of Benn: Speeches, Diaries, Letters and Other Writings (Arrow, 2015), p.21. 
foundly committed to the EU. Many of these Europhiles have an intense dislike for their Eurosceptic compatriots, tracing the latter's resistance often to an arrogant, isolationist, ridiculously nostalgic "Little Englander" mentality. In others they recognise a more socialist and internationalist motivation for some current Euro-sceptics. Hence, when he was a Labour Party backbencher, the leader of the Labour Party (from September 2015 to April 2020) Jeremy Corbyn frequently expressed similar concerns to those of Tony Benn. For example, speaking to a television reporter during the $1996 \mathrm{La}-$ bour Party conference he warned that: "We have a European bureaucracy totally unaccountable to anybody. Powers have gone from national parliaments. They haven't gone to the European Parliament, they've gone to the [European] Commission and to some extent to the Council of Ministers." For Corbyn, the European institutions have long pushed a neoliberal agenda, at the expense of workers' rights. Corbyn led the Labour Party during the post-referendum period. In that role he supported Remain and argued for a second referendum. However, given his previous Eurosceptic stance, many critics have questioned his commitment to the Remain cause.

Elsewhere the intensity of public resistance to the EU has increased notably since Cameron's 2013 commitment to hold a Brexit referendum. It is now common to hear the objection that the EEC was good as a free trade area but that, especially following the 1992 Maastricht Treaty, the EU

4 "Jeremy Corbyn Opposes the EU", https:// www.youtube.com/watch?v=sJSiwNWb7pY accessed 11 November 2019. has exceeded a purely economic remit and increasingly aspires to become a European superstate. This is a recurring theme of Leavers, especially those in UKIP and the Brexit Party, and of course not least Nigel Farage. Karl McCartney, Conservative MP for Lincoln from 2010 until he was voted out in the 2017 general election (following a series of scandals relating to expenses and other alleged misconduct), warns that the EU has long been pursuing a "centralising and Superstate-building agenda", which the Brexit vote has "re-energised". ${ }^{5}$ Once the EU establishment - led by the Germans - has succeeded in its "foul integration", "former [national] Parliaments [will be left] with 'collecting bins', 'street lights' and regional or local government-type devolved powers to play with."

A Stepwise binary logistic regression of the British Social Attitudes data from 2015 revealed that the "key influences of on [UK] attitudes towards the European Union" were as follows. ${ }^{6}$

${ }^{5}$ Karl McCartney, "The Superstate into which the EU is evolving makes our departure all the more urgent", Brexitcentral, 28 September 2019, https:// brexitcentral.com/the-superstate-into-which-theeu-is-evolving-makes-our-departure-all-the-moreurgent/ accessed 11 November 2019.

6 The table appears in John Curtis, How Deeply Does Britain's Euroscepticism Run? (British Social Attitudes, 2015), p.12. Curtis provides the following: “*** Especially strong relationship/Eurosceptic: Wishes either to leave the EU or to stay but reduce the EU's powers./Europhile: Wishes to remain in the $\mathrm{EU}$ as it is or with the EU having increased powers./ Source: Stepwise binary logistic regression of BSA 2015 data." 


\begin{tabular}{|l|l|}
\hline \multicolumn{2}{|c|}{ Dependent variable is } \\
\hline \multicolumn{1}{|c|}{ Continue vs Withdraw } & \multicolumn{1}{c|}{ Eurosceptic vs Europhile } \\
\hline Undermines identity*** & Undermines identity ${ }^{* * *}$ \\
\hline Economy if leave ${ }^{* * *}$ & Immigration if leave \\
\hline Economy if stronger links & Conservative or UKIP supporter \\
\hline Immigration if leave & Economy if stronger links \\
\hline Strength of European identity & Strength of European identity \\
\hline
\end{tabular}

\section{b. The immediate context of the 2016 Brexit referendum}

The main actors in the Brexit chaos have become far too familiar in the UK at least. On the Remain side, initially we can identify David Cameron the then-UK Prime Minister and leader of the Conservative Party, as well as George Osborne the UK Chancellor of the Exchequer, who was also a Conservative MP, and Alan Johnson the face of the official Remain campaign and a Labour MP. On the Leave side, major roles were played by Dominic Cummings the strategist for Vote Leave, Boris Johnson who led the official Leave campaign and who is a Conservative MP, as well as other Conservative MPs, most notably Michael Gove and David Davis. Finally, there was Nigel Farage, then the leader of the UK Independence Party (UKIP).

It was on 23 January 2013 in a muchanticipated speech, that David Cameron first promised to hold a new referendum on the UK's continuing EU membership. If re-elected in 2015, he said, the Conservative government would push for the renegotiation of the terms with the EU. Once the draft of that new treaty had been agreed by EU representatives, the UK electorate would be asked whether it wanted to stay in the EU under the new terms, or whether they wanted to leave the EU: "We will give the British people a referendum with a very simple in or out choice to stay in the EU on these new terms, or to come out altogether. ... It is time for the British people to have their say, it is time for us to settle this question about Britain and Europe."

Who was asking the question? For many commentators, Cameron's decision was an attempt to silence significant Eurosceptic voices within his own Conservative Party. However, one must be careful here because the situation was not so straightforward. Cameron faced continuing Tory discontent, but the true cause was the rise of UKIP and Cameron's awareness of the dangers it posed to Conservative votes in the then-upcoming 2015 election. UKIP had seen its support rise steadily especially during EU elections, where it polled $7 \%$ in $1999,16 \%$ in 2004 , and $16.5 \%$ in 2009. ${ }^{8}$ Even after Cameron's public commitment to hold a referendum, it went on to poll $27.5 \%$ in the 2014 EU elections. It had never attracted more than $3.2 \%$ of the vote in national elections, partly because it could never afford to field candidates in many seats. Nevertheless, UKIP's share was increasing: $1.5 \%$ in $2001,2.3 \%$ in 2005 , to $3.2 \%$ in 2010. The major thing on Cameron's mind might well have been that UKIP was making significant advances where individual Parliamentary seats became vacant (for example, because of the death of the incumbent). From a situation when they had almost always received less than $10 \%$ of the

7 BBC News, "David Cameron promises in/out referendum on EU", 23 January 2013 https://www. bbc.co.uk/news/uk-politics-21148282 accessed 11 November 2019.

8 Alex Hunt, "UKIP: The story of the UK Independence Party's rise”, BBC News, 21 November 2014 https://www.bbc.co.uk/news/uk-politics-21614073 accessed 13 November 2019. 
vote in by-elections, UKIP had witnessed increasing support starting with the Middleborough and Rotherham by-elections in November 2011 (where they attracted $11.8 \%$ and $21.7 \%$ of the vote, respectively). They steadily increased that share of the vote over subsequent months, even after Cameron's announcement, to the point where they received $59.7 \%$ in the Clacton by-election of October 2014 and had an MP elected, Douglas Carswell. (Carswell had forced the by-election by switching party allegiance from the Conservatives to UKIP.) UKIP's growing strength posed an increasingly real threat for the Conservatives and emboldened Euro-sceptics within the Conservative Party both in Parliament and outside it. Hence, Cameron was forced to honour his commitment to hold an "inout" referendum on EU membership soon after being re-elected on 7 May 2015.

\section{c. UK sovereignty}

In 2013, immigration had long been a highly visible phenomenon in most countries. In 2016, EU economic migration from Eastern Europe, especially from Poland, was particularly high; as was the flow of war refugees across Europe, predominantly from Syria, Afghanistan and Iraq. ${ }^{9}$ By June 2016 when the Brexit referendum took place, the European Migrant Crisis was at its height and dominated media reports across Europe, including in the UK. To many people, the crisis seemed likely to get much worse very quickly, not least due to the perceived

9 Eurostat, "Asylum Applicants in the EU" [2016], European Commission https://ec.europa.eu/ eurostat/news/themes-in-the-spotlight/asylum2016 accessed 11 November 2019. possibility of Turkey's accession to the EU. This was as true of UK public opinion as it was for countries inside the Schengen Area.

Concerns over immigration were inseparable from questions regarding the nation's ability to control its own borders. The fundamental issue was one of national sovereignty. Indeed, Brexit concerns over immigration are simply the latest expression of a deep nationalist strain within certain sections of the UK population. One of the most articulate defenders of a still very influential form of British nationalism was one of Farage's boyhood heroes, Enoch Powell. ${ }^{10}$ On 19 June 1971, Powell ended a speech to the Doncaster Conservative Association with the following warning.

"[Public o]pinion has been right to fasten upon sovereignty as the central issue [in relation to the UK's then-proposed membership of the EEC]. Either British entry is a declaration of intent to surrender this country's sovereignty, stage by stage, in all that matters to a nation, and makes a nation, or else it is an empty gesture, disgraceful in its hollowness alike to those who proffer and to those who accept it.... The question which the people of this country will have proposed to them [in the referendum to join the EEC] is: will you, or will you not, continue to be governed by the Queen in Parliament." 11

${ }^{10}$ Nick Assinder, "Why UKIP’s Nigel Farage is Enoch Powell's Political Heir", International Business Times, 21 May 2014 https://www.ibtimes.co.uk/ why-ukips-nigel-farage-enoch-powells-politicalheir-1449443 accessed 14 November 2019.

${ }^{11}$ Enoch Powell, "Extract from speech by the Rt. Hon. J. Enoch Powell MP at the Doncaster Conservative Association Gala, Doncaster Race Course, 2.30pm, Saturday 19 June 1971" (pp.13-14), in The Speeches of John Enoch Powell, Poll 4/1/7 File 2, June- 
Powell was clearly horrified by the prospect of joining the EEC. Speaking in the House Commons two days later, he was explicit about his reasons.

"The whole development and nature of our national identity and consciousness has been not merely separate from that of the countries of the Continent of Europe but actually antithetical; and, with the centuries, so far from growing together, our institutions and outlook have rather grown apart from those of our neighbours on the continent. In our history, both recent and earlier, the principal events which have placed their stamp upon our consciousness of who we are, were the very moments in which we have been alone, confronting a Europe which was lost or hostile. That is the picture, that is the folk memory, by which our nation has been formed."12

For many on the right in the contemporary UK - I suspect, particularly in England - the resentment towards the EU was and still is strengthened by resentment over the loss of the British Empire. Along with this resentment at the loss of Empire goes what is to many other UK citizens a startling confidence that the UK can regain its standing as a quasi-imperial power if it were not a member of the EU. The picture is complex however, because nationalism and the desire to regain an imperial past need not go together. For example, in a speech given

September 1971, pp.133-34; http://enochpowell. info/wp-content/uploads/Speeches/June-Sept $\% 20$ 1971.pdf

${ }_{12}$ Enoch Powell, Speech in the House of Commons (21 January 1971), Hansard HC Deb 21 January 1971, vol. 809, c.1376 https://api.parliament.uk/ historic-hansard/commons/1971/jan/21/europeaneconomic-community\#column_1376 accessed 8 November 2019. on 15 January 1971, Powell referred to the UK as "a nation which is in the throes of rescuing its identity from the delusions and the deceits of a vanished Empire and Commonwealth". Indeed, he thought that a nation in such a state could never "at the same time undertake to merge that identity again in half the continent of Europe." ${ }^{13}$ Like his hero, Nigel Farage has placed little emphasis on the possibility of Britain recreating its imperial power in a post-colonial era, while obviously maintaining a fervently anti-EU position.

It is important to acknowledge that there is something of a paradox here. As just noted, one of the most fundamental sources of anti-EU sentiment in the UK (and many other countries) has long been that a nation's sovereignty is profoundly compromised by its EU membership. The paradox, in the UK case at least, is that during the referendum and subsequently many leavers have claimed both that UK sovereignty was severely compromised by EU membership, and that it would be fairly painless to leave the EU. In July 2017, the staunchly pro-Brexit Liam Fox, at the time the International Trade Secretary, assured listeners to the BBC's Today radio programme that "The free trade agreement that we will have to do with the European Union should be one of the easiest in human history." ${ }^{14}$ Yet,

${ }^{13}$ Enoch Powell, "Speech by the Rt. Hon. J. Enoch Powell M.P. to a Young Unionist Rally at the Apprentice Boys Memorial Hall, Londonderry, at $8 \mathrm{pm}$, Friday $15^{\text {th }}$ January 1971 ", p.15, 15 January 1971, in The Speeches of John Enoch Powell, Poll 4/1/7 File 4, January-March 1971; http://enochpowell.info/ wp-content/uploads/Speeches/Jan-March\%201971. pdf accessed 8 November 2019.

${ }^{14}$ Quoted in Matthew Weaver, "Liam Fox: EU trade deal after Brexit should be 'easiest in history' 
many people are left wondering, why it is that if one honestly believed that leaving could be so simple, would one also believe that the UK was being significantly coerced into obeying EU laws? If the UK were to be so strong, then it could resist any unreasonable EU demands and thereby maintain its own sovereignty.

\section{d. Increasing threats and violence}

The lead-up to the EU referendum vote and the time since have seen a marked increase in the number of reported hate crimes, levelled primarily against migrants and Remain supporters. Such crimes include the distribution (in Huntingdon Cambridgeshire) of cards saying: "Leave the EU/ No more Polish vermin". ${ }^{15}$ However, the most shocking incident was the murder of Jo Cox MP for Batley and Spen on 16 June 2016, exactly a week before the referendum vote. Jo Cox's murderer was found to have deep far-right sympathies. While committing the attack, he reportedly shouted "This is for Britain. Britain will always come first," a clear allusion to the far-right group Britain First. ${ }^{16}$

The higher rate of racist attacks persisted after the announcement of the referendum result on 24 June 2016. UK Home

to get”, The Guardian, 20 July 2017 https://www. theguardian.com/politics/2017/jul/20/liam-fox-ukeu-trade-deal-after-brexit-easiest-human-history accessed 13 November 2019.

${ }^{15}$ BBC News, Anti-Polish cards in Huntingdon after EU referendum", BBC News, 26 June 2016 https://www.bbc.co.uk/news/uk-england-cambridgeshire-36633388

${ }_{16}$ BBC News, "Labour MP Jo Cox 'murdered for a political cause”, BBC News, 14 November 2016. The murderer was a 53 year old, named Thomas Mair, who received a full life sentence.
Office figures published in October 2018 revealed that the police in England and Wales recorded 94,098 hate crimes in the year to March 2019, which was $123 \%$ higher than five years previously. ${ }^{17} 76 \%$ of these were recorded as "race hate crimes" and 9\% were recorded as "religious hate crimes." ${ }^{18}$ The Home Office conjectured that part of the reason for the increase was better reporting and recording of such crimes. Nevertheless, it noted also that the 2016 referendum and the 2017 terrorist attacks were associated with sudden increases in hate crimes. Violence remains a profound concern, not least due to the increasing number of threats being made against MPs, especially against female Remain MPs.

Just as shocking in many ways are the attitudes towards violence that were revealed in October 2019 by the Future of England Survey:

- Most Leave voters across all three countries think violence towards MPs is a 'price worth paying' for Brexit - $71 \%$ in England, $60 \%$ in Scotland and $70 \%$ in Wales. The majority of Remain voters across all three countries think violence towards MPs is a 'price worth paying' to Remain

${ }^{17}$ Home Office, Hate Crimes, England and Wales, 2017/18, 16 October 2018, p.7; https://assets.publishing.service.gov.uk/government/uploads/ system/uploads/attachment_data/file/748598/hatecrime-1718-hosb2018.pdf accessed 11 November 2019.

18 The report acknowledges that anyone incident might have multiple causes, meaning that it might appear in more than one category (so some incidents might be recorded as both race hate crimes and religious hate crimes. (Home Office, Hate Crimes, p.7). 
- 58\% in England, 53\% in Scotland and $56 \%$ in Wales.

- A majority of Remain voters across all three countries think protests in which members of the public are badly injured are a 'price worth paying' to stop Brexit and remain in the EU 57\% in England, 56\% in Scotland and $57 \%$ in Wales. Even larger majorities of Leave voters in all three countries think protests in which members of the public are badly injured are a 'price worth paying' to achieve Brexit 69\% in England, 62\% in Scotland and $70 \%$ in Wales." ${ }^{19}$

Obviously, when violence becomes so acceptable within a liberal democracy, one must be deeply fearful for the future of that country. When there are political tools to bring about change, but violence is still seen as being a legitimate means for achieving the same end, then one should question citizens' claims that they are civilised.

\section{Lies}

\section{a. "Project Fear"}

The growing acceptability of violence across the Brexit spectrum is not the only sign of the alarming decay of the UK's public culture. Both the referendum campaign and the subsequent political and civic manoeuvrings have been characterised by deception and scare mongering. It was

${ }^{19}$ Cardiff University, "Future of England Survey reveals public attitudes towards Brexit and the union", Cardiff University, 24 October 2019, https:// www.cardiff.ac.uk/news/view/1709008-future-ofengland-survey-reveals-public-attitudes-towardsbrexit-and-the-union a common line of attack from most sides of the referendum campaign. Eventually, the Leave campaign and Nigel Farage in particular won the public relations battle, when it succeeded in branding Remainers as the authors of "Project Fear". The key "myths" allegedly perpetrated by Remainers have been neatly summarised by Professor David Paton of the Nottingham University Business School, in a blog from December 2018, on the Spectator magazine website. ${ }^{20}$

"Myth 1 . The UK economy could shrink by eight per cent in a single year under no deal (Project Fear, Bank of England version)"21

"Myth 2. Leaving with no deal will lead to GDP being 7.6 per cent lower in 2035-6 than staying in the EU (Project Fear, Treasury version)"22

"Myth 3. No deal will decimate trade from the EU, our biggest partner"

"Myth 4. If we leave without paying the $£ 39$ bn to the EU it will devastate Britain's international credibility"

20 David Paton, "Ten myths from the 'no deal' Project Fear", The Spectator, 1 December 2018 https://blogs.spectator.co.uk/2018/12/ten-myths-fromthe-no-deal-project-fear/ accessed 12 November 2019.

${ }^{21}$ Links to: Bank of England, "EU withdrawal scenarios and monetary and financial stability", Bank of England, 28 November 2018 https://www. bankofengland.co.uk/report/2018/eu-withdrawalscenarios-and-monetary-and-financial-stability accessed 12 November 2019.

${ }^{22}$ Links to: HM Government, "EU Exit: Longterm economic analysis November 2018”, HM Government https://assets.publishing.service.gov.uk/ government/uploads/system/uploads/attachment_ data/file/760484/28_November_EU_Exit_-_Longterm_economic_analysis_1_.pdf accessed 12 November 2019. 
"Myth 5. In a no-deal Brexit, WTO rules would require the enforcement of a hard border between the Republic of Ireland and Northern Ireland"

"Myth 6. No deal will lead to prices in the shops going up"

"Myth 7. Since the Referendum, the UK has become one of the slowest growing members of the G7"

"Myth 8. Investment into the UK has plummeted since the referendum and will decrease further under no deal"

"Myth 9. No deal will see border trade grind to a halt"

"Myth 10. A no-deal Brexit would mean families having to do without Christmas tre$\mathrm{es}^{\star} /{ }^{\star}$ feel free to substitute food, water, medicines, Mars bars or whatever is the next item in the Project Fear crosshairs."

There is insufficient space to consider each of these points, so as to determine the extent to which they capture reality. All I can suggest for the moment is that many of them look far less mythical now than they have done to many people over the past three years.

\section{b. Anti-experts narrative}

What we can say is that, as just noted, the Leave narrative of Remainers as "Remoaners," or additionally as agents of "Project Fear" has been very effective, in the sense that apparently a significant proportion of the UK population believed it at least on referendum day. The narrative was associated with the Leave attack on expertise. This link was expressed most starkly in the then-Justice Secretary Michael Gove's response when asked (in a Sky News interview during the campaign) which economists supported Brexit: "people in this country",
Gove replied, "have had enough of experts" ${ }^{23}$ Gove's remark was endorsed repeatedly by Leavers, and became notorious among Remainers as marking a "post-truth" low-point in the campaign. The favoured targets for the remark rapidly became the Treasury and the Bank of England, especially its Governor Mark Carney. Both of these were portrayed as prime stooges for the government's Remain campaign. In a particularly disturbing turn, some sections of the right-wing press accused the judges sitting in the High Court of England and Wales of being "enemies of the people," when they determined in November 2016 that the law required Theresa May's government to gain parliamentary approval of any future withdrawal agreement. ${ }^{24}$

The claim became one of the standard responses when statistics were published that appeared to support the pro-Remain case. It legitimised ignorance over evidence and so served to closedown rational debate in favour of prejudice and wilfully blind emotion. The debates around immigration provided many striking instances of this embrace of ignorance. One of the most famous examples here was a refugee poster that UKIP unveiled during the referendum campaign. The poster showed a column of young men walking, all were poorly dressed and most had what many British people saw

${ }^{23}$ Henry Mance, "Britain has had enough of experts”, Financial Times, 3 June 2016 https://www. ft.com/content/3be49734-29cb-11e6-83e4-abc22d$5 \mathrm{~d} 108 \mathrm{c}$

${ }^{24}$ James Slack, "Enemies of the People", Daily Mail, 4 November 2016 https://www.dailymail. co.uk/news/article-3903436/Enemies-people-Furytouch-judges-defied-17-4m-Brexit-voters-triggerconstitutional-crisis.html accessed 14 November 2019. 
as an Eastern European appearance. The poster read: "BREAKING POINT / The EU has failed us all / We must break free of the EU and take back control of our borders. Leave the European Union on $23^{\text {rd }}$ June." The poster disturbed many people for its implicit racism. This revulsion increased when it became known that the column actually depicted migrants crossing the Croatia-Slovenia border in 2015, not migration into the EU, let alone migration into the UK. ${ }^{25}$ Even prominent Leavers such as Michael Gove and Nigel Adams expressed their disgust at the poster.

Despite the poster being reported to the police for allegedly inciting racial violence, Nigel Farage (who fronted the poster campaign as UKIP's then-leader) has remained defiant. In a 2018 interview with The Yorkshire Post newspaper, he claimed that the poster played a decisive role in the referendum: "In some ways it won us the referendum," he said, "because it kept us focused on the danger of open borders." ${ }^{26}$ Alex Sorbel (Labour Co-Op) MP for Leeds North West has observed: "The breaking point poster created a culture of fear and intolerance. The fact that Nigel Farage has no regrets is a reflection on the hard right and their lack of humanity. ${ }^{27}$ The chair of the House of Commons Home Affairs Committee, Yvette Cooper (Labour) MP for Normanton, Pontefract and Castleford not-

${ }^{25}$ Slovenia joined the EU in 2004 and Croatia joined in 2013.

${ }^{26}$ Arj Singh, "Nigel Farage says controversial anti-migrant poster 'won the referendum' for Brexit", 19 October 2018 https://www.yorkshirepost.co.uk/ news/latest-news/nigel-farage-says-controversialanti-migrant-poster-won-the-referendum-for-brexit-1-9404360 accessed 13 November 2019.

${ }_{27}$ Singh, "Nigel Farage says". ed that "Sadly Nigel Farage thinks this kind of thing is all a game but the reality is that it meant we had an increase in hate crime. It should be possible to have a sensible honest debate about Europe or about immigration without resorting to dishonesty and division".28

Farage sees open borders as a danger to the UK because of the alleged tendency of migrants to impose significant net burdens on the host country. In particular, they are accused of increasing pressure on school places, school resources, housing, and the National Health Service (NHS). Farage's message has been especially effective among the white working class. As noted in 2017 in the Harvard Business Review, "Studies have found that areas that supported Leave had an overall weaker economic structure, with lower levels of income and life satisfaction, fewer high status-jobs, an aging demographic, and lower levels of educational attainment." ${ }^{29}$

The anti-expertise narrative bolsters Farage's confidence and that of many of his ilk. It also serves to validate their unreflective faith in their own "common sense", and consequently their resentment against experts who present evidence which contradicts their prejudices (that low-wage migration has no measurable effect on the wages of the low-paid for example). Some realities

28 Singh, "Nigel Farage says".

29 Thiemo Fetzer, "Did Austerity in the UK Lead to the Brexit Crisis?", Harvard Business Review, 23 August 2019 https://hbr.org/2019/08/did-austerityin-the-uk-lead-to-the-brexit-crisis accessed 13 November 2019. Citing Federica Liberini, Andrew J. Oswald, Eugenio Proto, and Michela Redoano, Was Brexit Caused by the Unhappy and the Old?, September 2017, Institute of Labor Economics Discussion Paper Series IZA DP No. 11059, http://ftp.iza.org/ dp11059.pdf accessed 13 November 2019. 
are harder to dismiss of course. For example, it is clear that the NHS relies on migrant workers (nurses, doctors, and so on) and that even with those workers an acute shortage of medical professionals exists in the UK's health services. Plenty of posts are waiting for UK citizens in this and other sectors. No matter what one's prejudices, it is patently obvious to anyone who uses such sectors that migrants are not preventing Britons from taking those jobs.

Many of those who reject Farage's assertion that open borders harm UK citizens argue that rather than being the result of immigration or benefit scroungers, the problems that motivated Leavers (poor schools, housing, health services, and so on) result largely from years of austerity. This suite of policies was introduced by the Coalition government in 2010 and was continued with even greater vigour by the Conservatives once the Coalition ended at the 2015 general election. As government figures themselves demonstrate, there was a direct correlation between deepening austerity and growing popular support for UKIP. This means that Cameron and Osborne's economic policies were directly responsible for the electoral threat which forced them to promise an "in-out" referendum on EU membership. In short, their draconian neoliberal economics made them the authors of their own political downfall.

\section{c. Anti-elitism narrative}

The Leave campaign routinely presented itself as fighting a "metropolitan liberal elite" that has lost touch with the interests and democratic will of the people. They were especially hard on the "traitors" who inhabit the "Westminster bubble". Words such as "traitor", "surrender" and "betrayal" are employed much more frequently in British political discourse. They are used most frequently by the hardliners who wish the UK to leave the EU without a deal. Those whom Brendan O'Neill, the editor of the internet-based free speech magazine Spiked, has called "the Remainer elite" - or the leaders of "the Remainer tyranny" - are regularly attacked in this way. ${ }^{30}$ For example, in late September 2019, BBC Radio 4's Today programme broadcast vox pop interviews with members of the general public. One particularly vicious contribution recalled the fate of a Roman Catholic traitor who was executed for attempting to blow up the Houses of Parliament in October 1605: "Burn them all," the person said, "like Guy Fawkes."31

It has long been a standard trope of "Vote Leave" and UKIP and now the Brexit Party then, that by seeking a no-deal Brexit they are fighting for the "British people" against a Remainer liberal elite. In reality, the majority of the Leave leadership are all part of an elite. Hence, Dominic Cummings, the key strategist for the Vote Leave campaign, attended the fee-paying Durham School before graduating with a First in Ancient and Modern History from Exeter College, Oxford. Alexander Boris de Pfeffel Johnson attended the European School Brussels 1, then went to prep school at the

${ }^{30}$ Brendan O’Neill, “The Remainer Tyranny”, Spiked, https://www.spiked-online.com/2019/09/08/ the-remainer-tyranny/ accessed 11 November 2019.

${ }^{31}$ See for example, Gerrard Kaonga, "Brexiteer fury at 'traitors' and 'disgraceful' Remainer MPs broadcast on BBC Radio 4", Daily Express, 27 September 2019 https://www.express.co.uk/news/ uk/1183378/Brexit-News-update-latest-Boris-Johnson-vote-Remain-leave-Today-Programme 
fee-paying Ashdown House before entering Eton, before graduating with an Upper Second Class degree in Ancient Literature and Classical Philosophy from Balliol College Oxford. While at Oxford, Johnson studied with future Conservative Party leaders William Hague and David Cameron, and the future Secretary of State for Skills Nick Boles, as well as Jeremy Hunt and Michael Gove who were two of the other contenders for the Conservative Party leadership that ultimately made Johnson Prime Minister of the UK in 2019.

Michael Gove was also Johnson's coleader of the official Leave campaign. As a child, Gove won a scholarship to a fee-paying school before meeting Johnson at Oxford where he followed him as President of the Oxford Union. Subsequently Gove has served with Johnson in various Conservative governments, and famously betrayed Johnson during the latter's first attempt to become Conservative Party leader immediately after Cameron resigned following his defeat in the 2016 referendum. ${ }^{32}$ Nigel Farage attended the fee-paying Dulwich College before becoming a multi-millionaire as a commodity trader in the metals market. Jacob Rees-Mogg is the MP for North East Somerset. He is best known as the leader of the virulent Brexiteer Parliamentary faction the European Research Group and the current the Leader of the House of Commons. His father edited The Times newspaper from 1967 to 1981 . He studied at Eton and then Oxford. (Unlike Johnson,

${ }^{32}$ Laura Kuenssberg, "Gove and Johnson: What happened?", BBC News, 30 June 2016 https:// www.bbc.co.uk/news/uk-politics-36679738 accessed 12 November 2019.
Rees-Mogg studied at Trinity College). He then worked in the City of London, before founding a very successful hedge-fund business, which itself has done very well out the Brexit chaos. In November 2016, he was estimated to be worth $£ 55$ million, and with his wife to be worth up to $£ 150$ million. ${ }^{33}$ (Rees-Mogg's manners and dress have led to being known as "the Member of Parliament for the Eighteenth-century".) Taking all of these facts into account, it seems that what really concerns the Leave campaign about the alleged "liberal elite" behind the Remain vote is not its elitism, but rather its liberalism. Indeed, as Jan-Werner Müller has noted "populists have no problem with representation as long as they are the representatives; similarly, they are fine with elites as long as they are the elites leading the people." 34

Lies continue to proliferate in the current Brexit debate. Many people look to the current Prime Minister and his political advisor Dominic Cummings as significant sources of this misinformation. There have been a number of attacks on Johnson's honesty. He was sacked from The Times newspaper for fabricating a news story, he was sacked from the Conservative shadow frontbench because he lied to the Party's then-leader Michael Howard over an affair that he (Johnson) was having. ${ }^{35}$ Other allegations have been made against him.

${ }^{33}$ David Oldroyd-Bolt, "The Many, Many Millions of Mogg”, Spectator Life, 3 November 2016 https://life.spectator.co.uk/articles/many-many-millions-mogg/

${ }^{34}$ Jan-Werner Müller, What is Populism? (Penguin, 2017), p.30.

35 BBC News, "Eddie Mair vs Boris Johnson", BBC News, 24 March 2013 https://www.youtube. com/watch?v=ZAxA-9D4X3o 
(Famously, he even refuses to confirm how many children he has fathered.) The former Secretary of State for Skills Nick Boles resigned the Conservative whip in April 2019 over Brexit, and in a Channel 4 News interview in November 2019, he described Boris Johnson as "morally unfit to be Prime Minister." He explained: "Boris Johnson... [is] an entirely amoral figure, he's betrayed everybody in his life, he lies about everything, he is wedded to no principle, no belief, he will say anything to get ahead, to get power." ${ }^{36}$ Even the convicted fraudster Conrad Black has said that he does not fully trust Johnson.

One of the most infamous examples of a profoundly misleading Leave claim was painted prominently on the side of the very high-profile "Vote Leave" campaign bus. The slogan read: "We send the EU $\mathfrak{E 3 5 0}$ million a week/let's fund the NHS instead Vote Leave/Let's take back control". Johnson and the other Vote Leave leaders posed regularly in front of the bus during the campaign. Its famous claim was widely

${ }^{36}$ Nick Boles, "Neither Jeremy Corbyn or Boris Johnson are "morally fit" to become the next Prime Minister according to former MP, Nick Boles", Channel 4 News, 12 November 2019 https://www.facebook. com/Channel4News/videos/1423135621166917/ The programme was Channel 4 News. The passage reads: "Both Boris Johnson and Jeremy Corbyn are morally unfit to be Prime Minister. For very different reasons. Boris Johnson because he's an entirely amoral figure, he's betrayed everybody in his life, he lies about everything, he is wedded to no principle, no belief, he will say anything to get ahead, to get power. Jeremy Corbyn because of course he's basically consorted with terrorists and murderous thugs throughout his life, all in favour of sort of abstract ideas like all totalitarian leaders, he's much more interested in movement than in people. And neither of them is fit to be Prime Minister." attacked. It was shown to take no account of the rebate and other income which the UK receives from the EU. In 2018, without any rebate or other income from the EU the UK would have paid $£ 17.4$ billion. ${ }^{37}$ However, the UK automatically received a rebate of $£ 4.2$ billion, taking the UK's contribution to $£ 13.2$ billion. In addition the EU spent $£ 4.3$ billion on UK public services and an unrecorded amount also goes to the UK's private sector. On that basis, the UK's net contribution in 2018 was a maximum of $£ 8.9$ billion. That equates to a maximum net contribution of $£ 171$ million per week,

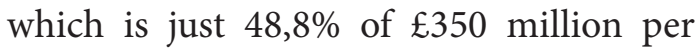
week claimed by Vote Leave.

One of the most worrying examples of the trend towards the blatant normalisation of political deceit was the Johnson government's refusal in November 2019 to release until after the upcoming general election, the official report into the Russian government's alleged use of social media to misinform and meddle in the 2016 Brexit referendum..$^{38}$ This move raises fundamental questions about the quality and robustness of UK democracy. This is the subject to which I will turn next.

${ }^{37}$ Full Fact, "The UK's EU membership fee", Full Fact, 8 July 2019, drawing on House of Commons figures https://fullfact.org/europe/our-eumembership-fee-55-million/ accessed on 12 November 2019.

${ }^{38}$ Dan Sabbagh, "No 10 accused of ignoring evidence of Russian interference", The Guardian, 6 November 2019 https://www.theguardian.com/ politics/2019/nov/06/no-10-accused-of-ignoringevidence-of-russian-interference accessed on $12 \mathrm{No}$ vember 2019. 


\section{UK democracy}

\section{a. Weak and disorderly government}

On the day that the Brexit referendum result was declared, David Cameron announced his intention to resign as Conservative Party leader and hence as UK Prime Minister. That announcement triggered an acrimonious campaign for the leadership of the Conservative Party. By the time Theresa May was elected party leader and Prime Minister on 13 July 2016, key Leave campaign friends had become bitter enemies. Gove had betrayed Johnson rather spectacularly, and in many people's eyes neither man retained any semblance of competence or dignity. Even Nigel Farage had resigned as UKIP leader nine days earlier.

Over the next three years, Theresa May struggled to find a workable majority in Parliament. She called the 2017 election in a desperate attempt to silence both Leave and Remain critics within her own parliamentary party and to increase the number of Conservative MPs who were willing to vote for the transition deal she had negotiated with the EU. May lost her majority at that election and was forced to form a parliamentary alliance with the Democratic Unionist Party (DUP). This arrangement was unable to save her and ultimately she proved unable to govern effectively. She resigned, leading Johnson to replace her on 24 July 2019.

\section{b. The democratic status of the referendum}

We can ask questions about the democratic status of the Brexit referendum. Firstly, constitutionally in the UK referendums have a merely "advisory" status. As such, Parliament is not required to enact them.
That said, prior to the result coming in, every major party had promised to obey the result of the referendum. Undoubtedly, many people made that promise in the belief that their side would win. Yet, in an ironic twist, prior to the result being announced the only person to raise the possibility of disputing the outcome was Nigel Farage, who said publicly that he would seek to have the result overturned if Remain won by a small majority. In an interview that he gave to the Daily Mirror newspaper a little over five weeks before the vote, he was unequivocal on the point: "In a 52-48 referendum this would be unfinished business by a long way", he said, "If the Remain campaign win two-thirds to one-third that ends it." ${ }^{39}$

Even though Farage himself has not questioned the legitimacy of the actual result, he did have a point. It is usual in other countries for major constitutional changes to have to be voted for by a two-thirds majority, with a turn-out of two-thirds of the electorate. On that basis, the Leave win (which was of course the mirror-image of Farage's hypothetical Remain win) would not have been large enough to lead Parliament to trigger Article 50. That said, Cameron did not apply the convention that would be usual abroad when setting-up the referendum, so Leave carried the day.

c. The erosion of trust in parliamentary institutions and mechanisms

Even if one ignores these vitally important issues, UK democracy is confronted by

39 BBC News, Nigel Farage: Narrow Remain win may lead to second referendum", $B B C$ News, 17 May 2016, https://www.bbc.co.uk/news/uk-politicseu-referendum-36306681 accessed 13 November 2019. 
other significant problems. In many ways, the UK faces a legitimation crisis. There is a widespread belief within the UK that the recent Brexit debates and votes in Westminster over May's deal and then Johnson's deal, warn of the death of UK democracy. There is an understandable and widespread frustration that the process is taking too long, that Parliament has still not "got Brexit done". Moreover, the vicious language and tone used by many MPs, of all parties, genders and sides of the Brexit debate, are taken to show that the institutions and mechanisms of government are, in the favourite cliché of the time, "broken". This accusation comes from every side of the House of Commons, the media and the wider society. Often, it is combined with the accusation that the "Leave" will of the British people is being frustrated by an undemocratic "Remain" "elite" or "establishment". For example, Parliament and courts made it clear that they would prosecute Boris Johnson if he went through with his threat to break the law by not asking the EU for an extension following Parliament's failure to pass his new deal by 19 October $2019 . .^{40}$ In response, Brendan O'Neill, the editor of the website Spiked, protested that:

“... we have now reached the "keep us in the EU or we will send you to jail' stage of the Remainer tyranny. This furious, anti-democratic wing of the elite, who make up the majority of the contemporary establishment, has been drifting towards extreme authoritarianism for two years now. They openly di-

40 The law took the form of the EU Withdrawal (No.2) Act - the so-called Benn Act - supplemented by the Letwin Amendment to the government's approval motion for its deal. scuss overriding the largest democratic vote in British history. They condemn newspapers that use strong language to describe Remainer extremism." ${ }^{41}$

To address the underlying issues here, it is necessary to examine the democratic credentials of the Brexit referendum in greater depth. This is needed because many of the disputes can be traced to the competing considerations at work in any modern democratic system. One universally-accepted criterion in a democracy is that the people must make the decision themselves, in this case through voting. This is the "self-determination" condition. Another widely-accepted criterion is that a decision is democratic to the extent that when voting the electorate were sufficiently clear about the meaning of the choice they were being asked to make. This is the "competence" condition. In other words, a decision is democratic to the extent that the people understand the reality of the situation in which they are making the decision (the economic and political facts of EU membership, in this case). Moreover, it is democratic to the extent that the electorate understand what is likely to happen if one leaves or remains. The idea is intuitively appealing: ask yourself, in what sense is it a free choice when you drink a cup of coffee without knowing that it has been poisoned? In the Brexit context, both sides - Leave and Remain - invoked the competence condition throughout the referendum campaign. For example, this is what the Leave side said made them so angry about "Project Fear":

41 Brendan O'Neill, “The Remainer Tyranny”, Spiked, https://www.spiked-online.com/2019/09/08/ the-remainer-tyranny/ accessed 11 November 2019. 
the Remainers were allegedly trying to undermine democracy by misleading voters.

What light do these two conditions shed on the democratic credentials of the Brexit referendum? It is a standard Leave trope that Parliament should agree legislation to exit the EU because "The British people voted for Brexit". Currently, the most vocal section of the Leave camp insists that "the British people" voted to leave without a deal of any type. However, this is an obviously spurious claim. Even when it was first announced, many people objected that the referendum question is exceptionally vague about what it meant in practice to "leave the European Union". During the campaign some Leavers argued that the UK should negotiate a deal with the EU and then leave, while others argued that the UK should leave without any deal. Among the group who argued to leave with a deal, there was no consensus about what sort of deal would be acceptable. At the very least on these grounds, it seems that the referendum did not come close to fulfilling democracy's competence condition.

The competence condition is also called into question by the subsequent surprise that many Leavers have expressed about the difficulty of negotiating the terms of the UK's departure. The UK's economy has been very closely integrated with the other member states since the UK joined the EEC in 1973. It is difficult to see how anyone who had even the most rudimentary understanding of this fact could have thought that disentangling these linkages could be either easy or quick.

The next consideration relates to the self-determination condition: for a decision to be democratic, "the people" must have voted for it. Deciding what classes as "the people" is notoriously difficult. The problem has taken on great significance in relation to the Brexit vote however, not least in relation to the different voting outcomes in the four constituent nations of the United Kingdom. They were as follows.

\section{EU Referendum votes, by nation of the UK*}

\begin{tabular}{|l|c|c|c|c|}
\hline \multicolumn{1}{|c|}{ Nation } & $\begin{array}{c}\text { Leave } \\
\text { (\% of vote; number of } \\
\text { votes) }\end{array}$ & $\begin{array}{c}\text { Remain } \\
\text { (\% of vote number of } \\
\text { votes) }\end{array}$ & Turnout & Which side won? \\
\hline England & $\begin{array}{c}\mathbf{5 3 . 4 \%} \\
15,188,406\end{array}$ & $\begin{array}{c}46.6 \% \\
13,266,996\end{array}$ & $73.0 \%$ & LEAVE \\
\hline Scotland & $\mathbf{3 8 . 0 \%}$ & $\mathbf{6 2 . 0 \%}$ & $67.2 \%$ & REMAIN \\
\hline Wales & $1,018,322$ & $1,661,191$ & $71.7 \%$ & LEAVE \\
\hline Northern Ireland & $\mathbf{5 2 . 5 \%}$ & $\mathbf{4 7 . 5 \%}$ & $62.7 \%$ & REMAIN \\
\hline
\end{tabular}

Source: BBC News, "EU Referendum: results”, BBC News, n.d., https://www.bbc.co.uk/news/politics/eu_ referendum/results accessed 4 November 2019.

This table indicates the complexity of the claim that "the British people voted for Brexit." The Scots did not, as the Scottish National Party repeatedly reminds Parlia- ment. The Northern Irish did not, even though Theresa May shored up her government by allying herself with the Leave-favouring Democratic Unionist Party. 


\section{d. Some reasons for (limited) optimism}

Undoubtedly there is a sense in which Brendan O'Neill is correct: UK democracy does face great problems. I have discussed the very aggressive tone of political debate, not merely in the UK Parliament but in the whole country; the tendency of those debates to descend not merely into the threat of violence but into violent acts themselves; the weakening of the authority of experts; and the associated belief that opinions based on prejudice are as valid as evidence-based judgements. Just as importantly of course, trust in Parliament as an institution and in parliamentarians as the heart of that institution has been severely undermined.

Despite the common perception in the UK and no doubt elsewhere of the crisis of UK democracy, I want to end with some optimistic observations. It is crucial to note that, despite the arguments and apparent lack of action, since the start of May's second term on 8 June 2017 we have witnessed the reassertion of the primacy of the UK Parliament over the UK government. The period from June 2016 to December 2019 demonstrated willingness and capacity of Parliamentarians to uphold not merely the UK's fundamental political values and procedures, but just as importantly to find ways to uphold their fundamental spirit and intent. Hence, on 4 December 2018 Theresa May was found in contempt of Parliament for not publishing the full legal advice that she was given over Brexit. ${ }^{42}$ Eight days later,

${ }^{42}$ Benjamin Kentish, "Theresa May government found in contempt of parliament over failure to publish full Brexit legal advice", The Independent, 4 December 2018 https://www.independent.co.uk/ news/uk/politics/contempt-parliament-vote-there- she narrowly survived a "No confidence" vote. From January to March 2019, Parliament refused to pass May's deal on four separate occasions. Throughout she faced strong and often ill-tempered opposition from many MPs and ordinary citizens. This opposition was particularly strong within her own party, and not least from the European Research Group, led by the idiosyncratic Jacob Rees-Mogg.

Unable to convince not merely Parliament but a large proportion of the British people that her deal was good enough to be accepted, Theresa May announced her intention to resign. That led eventually to Boris Johnson becoming Prime Minister on 24 July 2019. Since that time, Johnson has repeatedly sought to circumvent Parliament, most obviously by attempting to prorogue Parliament for an extraordinarily long period of time, so as prevent it from being able to appropriately scrutinise his new deal. This attempt to govern without proper parliamentary oversight and approval was prevented by various of the UK's highest courts. Ultimately, the UK Supreme Court annulled Johnson's attempted prorogation, and Parliament returned to sit again in Westminster on 25 September. Johnson attempted to push his deal through the House of Commons once again, proposing to allow it only three days to consider the new long and complex withdrawal document. In response, the Commons agreed in principle to accept the deal, but subject to a longer period of examination and debate. At this point Johnson called a general election, which was held on 12 December.

sa-may-brexit-legal-advice-government-geoffreycox-a8667086.html accessed 13 November 2019. 
People who care about UK democracy should find comfort in this frustrating and angry period. While the Official Opposition (Jeremy Corbyn's Labour Party) has been depressingly ineffective, other bodies and individuals have done much to defend parliamentary democracy in the UK. One can think of John Bercow the (now former) Speaker, Hilary Benn (Labour) MP for Leeds Central, Oliver Letwin (Conservative) MP for West Dorset, and Yvette Cooper (Labour) MP for Normanton, Pontefract and Castleford. One can think of many other politicians - both Leave and Remain who have resisted Johnson's attempts to circumvent Parliament. One can think also of the millions of ordinary citizens who have protested against it. One can think of the role of the courts. After all, this is a central part of what the Brexiteers have always said they wanted: namely, for the UK to "take back control." Parliamentary authorisation and judicial review are at the heart of UK democracy.

More fundamentally still, the divisions within the UK Parliament and its inability to agree about how to proceed over Brexit are themselves significant indications that the institution is truly democratic. According to a recent poll by the Observer magazine, in a re-run of the referendum $43 \%$ of the electorate would vote Remain, while only $1 \%$ less would Leave. ${ }^{43}$ Parliament's deep divisions and inactivity reflect the profound divisions within the UK electorate. Many

43 Toby Helm, "Brexit referendum should never have been called, say majority of voters", The Guardian, 26 October 2019, https://www.theguardian.com/ politics/2019/oct/26/opinium-poll-observer-ukvoters-regret-brexit-referendum-conservative-leadover-labour accessed 11 November 2019. voters, the media and even MPs themselves blame Parliament and the courts, rather than accepting this fact. Given their frustration with the Brexit deadlock and chaos, perhaps they should think instead that the UK Parliament represents the will of the UK electorate all too effectively.

\section{Conclusion: Ways forward?}

The UK has suffered significant damage since Cameron announced that there would be a Brexit referendum. The UK population trust Parliament much less than they used to. Uncertainty over Brexit has brought clear and significant economic costs. There is a reduced sense of social cohesion and a marked increase in reported hate crimes. There is a greater polarisation between the UK's historic self-images, whether those self-images be of a formerly great nation or empire damaged by the EU and immigration, or of the UK as an open, tolerant and multicultural country.

It is undoubtedly for these reasons and many others like them that a recent poll by the Observer newspaper shows that the majority (57\%) of the UK electorate thinks it would have been better if the 2016 referendum had never taken place. ${ }^{44}$ (Only 29\% said that the believed it should have been held.) Only $57 \%$ of those who voted Leave in 2016 now believe it was sensible to hold the referendum, whereas $32 \%$ thought it was not sensible.

${ }_{44}$ Toby Helm, "Brexit referendum should never have been called, say majority of voters", The Guardian, 26 October 2019, https://www.theguardian.com/ politics/2019/oct/26/opinium-poll-observer-ukvoters-regret-brexit-referendum-conservative-leadover-labour accessed 11 November 2019. 
What has been genuinely reassuring however, is that (despite what many hardline Brexiteers claim) many of those who voted Remain accepted the result of the referendum as authoritative and now insist that the UK leaves the EU. To be clear: while I have grave doubts about the democratic credentials of the Brexit vote, for me at least the reassuring feature of the formerRemainers' reaction is their acceptance of the moral force of what they believe to be the democratic will of the people.

A second referendum on a specific Brexit deal might offer a partial solution to some of these problems. It might help to rebuild political legitimacy and strengthen a much-weakened sense of the UK's common good. The problem is that it is not clear how many people would support a second referendum. In many ways, the Conservative victory in the 2019 UK General Election was a vote in order to decide whether to have that second referendum. It is interesting therefore that even though the Conservatives won huge majority of 80 seats (in a parliament of 650 seats), $53 \%$ of those who voted in the election voted for parties that promised either to hold a second referendum on Brexit or to cancel Brexit without holding a second referendum. (Indeed, while the Conservatives increased their number of seats very significantly, they increased their vote share by only $1.3 \%$.) Nevertheless, the UK does looks certain to leave the EU in 2020 and, currently, Remain supporters and parties on trying to find a new way forward. That said, the realities of negotiating the post-Brexit relations with the EU and the wider world seem to make it likely that Boris Johnson's new Conserva- tives government will face a great many challenges which until now it has sought to hide from the UK public. Unfortunately, it seems likely that the Brexit chaos is very far from being over.

\section{References:}

Assinder N., "Why UKIP's Nigel Farage is Enoch Powell's Political Heir", International Business Times, 21 May 2014 https://www.ibtimes.co.uk/why-ukips-nigel-farage-enochpowells-political-heir-1449443 (accessed 14 November 2019).

Bank of England, "EU withdrawal scenarios and monetary and financial stability", Bank of England, 28 November 2018 https://www. bankofengland.co.uk/report/2018/eu-withdrawal-scenarios-and-monetary-and-financial-stability (accessed 12 November 2019).

BBC News, "David Cameron promises in/out referendum on EU", 23 January 2013 https:// www.bbc.co.uk/news/uk-politics-21148282 (accessed 11 November 2019).

BBC News, "Eddie Mair vs Boris Johnson", BBC News, 24 March 2013, https://www.youtube. com/watch?v=ZAxA-9D4X3o

BBC News, "EU Referendum: results", BBC News, n.d., https://www.bbc.co.uk/news/politics/eu_referendum/results (accessed 4 November 2019).

BBC News, "EU Referendum: results", BBC News, n.d., https://www.bbc.co.uk/news/politics/eu_referendum/results (accessed 4 November 2019).

BBC News, "Labour MP Jo Cox 'murdered for a political cause", BBC News, 14 November 2016.

BBC News, Anti-Polish cards in Huntingdon after EU referendum", BBC News, 26 June 2016 https://www.bbc.co.uk/news/uk-englandcambridgeshire-36633388

BBC News, Nigel Farage: Narrow Remain win may lead to second referendum", $B B C$ News, 17 May 2016, https://www.bbc.co.uk/ news/uk-politics-eu-referendum-36306681 (accessed 13 November 2019).

Benn T., Encounter (January 1963), quoted in Ruth Winstone (ed.), Best of Benn: Speech- 
es, Diaries, Letters and Other Writings (Arrow, 2015), p.21.

Boles N., "Neither Jeremy Corbyn or Boris Johnson are "morally fit" to become the next Prime Minister according to former MP, Nick Boles", Channel 4 News, 12 November 2019 https://www.facebook.com/Channel4News/videos/1423135621166917/

Cardiff University, "Future of England Survey reveals public attitudes towards Brexit and the union", Cardiff University, 24 October 2019, https://www.cardiff.ac.uk/news/ view/1709008-future-of-england-surveyreveals-public-attitudes-towards-brexit-andthe-union

Curtis J., How Deeply Does Britain's Euroscepticism Run? (British Social Attitudes, 2015).

Eurostat, "Asylum Applicants in the EU” [2016], European Commission https://ec.europa.eu/ eurostat/news/themes-in-the-spotlight/asylum2016 (accessed 11 November 2019).

Fetzer T., "Did Austerity in the UK Lead to the Brexit Crisis?", Harvard Business Review, 23 August 2019 https://hbr.org/2019/08/didausterity-in-the-uk-lead-to-the-brexit-crisis (accessed 13 November 2019).

Full Fact, "The UK's EU membership fee", Full Fact, 8 July 2019, drawing on House of Commons figures https://fullfact.org/europe/our-eu-membership-fee-55-million/ (accessed on 12 November 2019).

Helm T., "Brexit referendum should never have been called, say majority of voters", The Guardian, 26 October 2019, https://www. theguardian.com/politics/2019/oct/26/opinium-poll-observer-uk-voters-regret-brexitreferendum-conservative-lead-over-labour (accessed 11 November 2019).

Helm T., "Brexit referendum should never have been called, say majority of voters", The Guardian, 26 October 2019, https://www. theguardian.com/politics/2019/oct/26/opinium-poll-observer-uk-voters-regret-brexitreferendum-conservative-lead-over-labour (accessed 11 November 2019).

HM Government, "EU Exit: Long-term economic analysis November 2018", HM Government https://assets.publishing.service.gov.uk/government/uploads/system/uploads/attachment_data/file/760484/28_November_EU_
Exit_-_Long-term_economic_analysis__1_. pdf (accessed 12 November 2019).

Home Office, Hate Crimes, England and Wales, 2017/18, 16 October 2018; https://assets. publishing.service.gov.uk/government/uploads/system/uploads/attachment_data/ file/748598/hate-crime-1718-hosb2018.pdf (accessed 11 November 2019).

Hunt A., "UKIP: The story of the UK Independence Party's rise", BBC News, 21 November 2014 https://www.bbc.co.uk/news/ukpolitics-21614073 (accessed 13 November 2019).

"Jeremy Corbyn Opposes the EU", https://www. youtube.com/watch?v=sJSiwNWb7pY (accessed 11 November 2019).

Kaonga G., "Brexiteer fury at 'traitors' and 'disgraceful' Remainer MPs broadcast on BBC Radio 4”, Daily Express, 27 September 2019, https://www.express.co.uk/news/ uk/1183378/Brexit-News-update-latestBoris-Johnson-vote-Remain-leave-TodayProgramme

Kentish B., "Theresa May government found in contempt of parliament over failure to publish full Brexit legal advice", The Independent, 4 December 2018, https://www.independent.co.uk/news/uk/politics/contempt-parliament-vote-theresa-may-brexit-legal-advicegovernment-geoffrey-cox-a8667086.html (accessed 13 November 2019).

Kuenssberg L., "Gove and Johnson: What happened?”, BBC News, 30 June 2016, https:// www.bbc.co.uk/news/uk-politics-36679738 (accessed 12 November 2019).

Liberini F., Oswald A. J., Proto E., Redoano M., Was Brexit Caused by the Unhappy and the Old?, September 2017, Institute of Labor Economics Discussion Paper Series IZA DP No. 11059, http://ftp.iza.org/dp11059.pdf (accessed 13 November 2019).

Mance H., "Britain has had enough of experts", Financial Times, 3 June 2016 https://www. ft.com/content/3be49734-29cb-11e6-83e4abc22d $5 \mathrm{~d} 108 \mathrm{c}$

McCartney K., "The Superstate into which the EU is evolving makes our departure all the more urgent", Brexitcentral, 28 September 2019, https://brexitcentral.com/the-superstateinto-which-the-eu-is-evolving-makes-our- 
departure-all-the-more-urgent/ (accessed 11 November 2019).

Müller J.-W., What is Populism? (Penguin, 2017), p.30.

O’Neill B., "The Remainer Tyranny", Spiked, https://www.spiked-online.com/2019/09/08/ the-remainer-tyranny/ (accessed 11 November 2019).

O’Neill B., "The Remainer Tyranny", Spiked, https://www.spiked-online.com/2019/09/08/ the-remainer-tyranny/ (accessed 11 November 2019).

Oldroyd-Bolt D., "The Many, Many Millions of Mogg”, Spectator Life, 3 November 2016 https://life.spectator.co.uk/articles/manymany-millions-mogg/

Paton D., "Ten myths from the 'no deal' Project Fear", The Spectator, 1 December 2018 https://blogs.spectator.co.uk/2018/12/tenmyths-from-the-no-deal-project-fear/ (accessed 12 November 2019).

Powell E., "Extract from speech by the Rt. Hon. J. Enoch Powell MP at the Doncaster Conservative Association Gala, Doncaster Race Course, 2.30pm, Saturday 19 June 1971" (pp.13-14), in: The Speeches of John Enoch Powell, Poll 4/1/7 File 2, June-September 1971, pp.133-134; http://enochpowell. info/wp-content/uploads/Speeches/JuneSept\%201971.pdf

Powell E., "Speech by the Rt. Hon. J. Enoch Powell M.P. to a Young Unionist Rally at the Apprentice Boys Memorial Hall, Londonderry, at $8 \mathrm{pm}$, Friday $15^{\text {th }}$ January 1971 ”, p.15, 15 January 1971, in The Speeches of John Enoch Powell, Poll 4/1/7 File 4, JanuaryMarch 1971; http://enochpowell.info/wp-
content/uploads/Speeches/Jan-March\%20 1971.pdf (accessed 8 November 2019).

Powell E., Speech in the House of Commons (21 January 1971), Hansard HC Deb 21 January 1971, vol. 809, c.1376 https://api. parliament.uk/historic-hansard/commons/1971/jan/21/european-economiccommunity\#column_1376 (accessed 8 November 2019).

Sabbagh D., "No 10 accused of ignoring evidence of Russian interference", The Guardian, 6 November 2019 https://www.theguardian. com/politics/2019/nov/06/no-10-accusedof-ignoring-evidence-of-russian-interference (accessed on 12 November 2019).

Singh A., "Nigel Farage says controversial antimigrant poster 'won the referendum' for Brexit”, 19 October 2018 https://www.yorkshirepost.co.uk/news/latest-news/nigel-farage-says-controversial-anti-migrant-posterwon-the-referendum-for-brexit-1-9404360 (accessed 13 November 2019).

Slack J., "Enemies of the People", Daily Mail, 4 November 2016, https://www.dailymail. co.uk/news/article-3903436/Enemies-people-Fury-touch-judges-defied-17-4m-Brexit-voters-trigger-constitutional-crisis.html (accessed 14 November 2019).

UK Government, "EU referendum", GOV.UK, n.d., https://www.gov.uk/government/topical-events/eu-referendum/about

Weaver M., "Liam Fox: EU trade deal after Brexit should be 'easiest in history' to get", The Guardian, 20 July 2017 https://www.theguardian.com/politics/2017/jul/20/liam-foxuk-eu-trade-deal-after-brexit-easiest-human-history (accessed 13 November 2019). 